\title{
IMPACT OF LITTER TURNOVER ON CARBON CYCLING IN FORESTS WITH DRAINED AND NATURALLY WET NUTRIENT-RICH ORGANIC SOILS IN LATVIA
}

\author{
Guna PETAJA, Latvian State Forest Research Institute "Silava”, Rigas street 111, LV-2169 Salaspils, Latvia; guna.petaja@ silava.lv \\ (corresponding author) \\ Kaspars POLMANIS, Latvian State Forest Research Institute "Silava", Rigas street 111, LV-2169 Salaspils, Latvia; \\ kaspars.polmanis@ silava.lv \\ Linards KRUMŠTEDS, Latvian State Forest Research Institute "Silava", Rigas street 111, LV-2169 Salaspils, Latvia; \\ linards.krumsteds@silava.lv
}

Litter production is a key parameter for estimation of forest soil carbon (C) stock. The aim of the study was to evaluate carbon stock in above and below-ground litter in forests with drained and naturally wet nutrient-rich organic soils in Latvia to improve National GHG inventory and to integrate data into AGM and EPIM models. To estimate C input with tree above-ground litter, sampling of litter was done in 46 research sites in Latvia. A modelling approach based on a literature review was used to estimate $\mathrm{C}$ input with tree below-ground litter and litter of ground vegetation. Our study highlights a connection between $\mathrm{C}$ input to soil with litter and stand characteristics - stand basal area, stand age and dominant tree species. There is a trend for $\mathrm{C}$ input from above- and below- ground litter to increase along with increasing stand basal area. In conifer stands the $\mathrm{C}$ input with ground vegetation increased with stand basal area, whereas for broadleaves the trend is reverse. There is still uncertainty regarding $\mathrm{C}$ input with below-ground litter and ground vegetation. In order to improve the modeling approach additional data and country-specific models are required.

Keywords: carbon input, litter production, fine roots, ground vegetation, organic soils

\section{INTRODUCTION}

Organic soils store large amounts of carbon (C) and can be both sinks and sources of greenhouse gases (GHG), depending on land management practice (Turunen et al., 2002; Yu et al., 2010). Drainage of soils lowers the emissions of methane $\left(\mathrm{CH}_{4}\right)$, but simultaneously it increases those of carbon dioxide $\left(\mathrm{CO}_{2}\right)$ and nitrous oxide $\left(\mathrm{N}_{2} \mathrm{O}\right)(\mathrm{Jauhiainen}$ et al. 2019). In many European countries drained peatlands are one of the largest sources of GHG emissions from agriculture and forestry (Drösler et al., 2008; Tubiello et al., 2016,). Drained organic soils in forest land in Latvia comprise about $384.76 \mathrm{kha}$ and are considered a major source of GHG emissions in the Land Use, Land Use Change, and Forestry (LULUCF) sector. Naturally wet organic soils comprise about 334.6 kha in Latvia and emissions from these soils are not calculated according to methodology so far elaborated for Latvia (Latvia's National Inventory Report., 2021). GHG emission factors from drained and naturally wet organic soils have relatively high uncertainty rate and regions of the same climate zone display significant differences (Lazdiņš and Lupiķis, 2019). Carbon stocks of different pools in forests need to be estimated with high accuracy due to the increasing need for recommendations for climate change mitigation measures in the LULUCF sector.

Litter production is a crucial parameter for estimation of forest soil $\mathrm{C}$ stock and its changes responding to climate change or management (Wutzler and Mund 2007, Feng et al. 2019). The process of litter decomposition drives C and other nutrient cycles in forest soils. GHG assessments would also benefit from accurate litter production data (Neumann et al. 2018). Litter can be divided in two major groups - above ground parts of plants, i.e., branches, leaves, reproductive organs etc., and below-ground organs - coarse and fine roots. Fine roots are non-woody roots 2 mm or less in diameter and they represent the main fraction of below-ground litter (Lehtonen 2005, Mccormack et al. 2015). Coarse roots produce relatively low amounts of litter over a short period of time because of slow turnover rates, therefore they are often excluded from below-ground litter estimation. It is challenging to quantify below-ground litter as roots are buried in soil and their collection (excavation) is time consuming and may cause artifacts. For this reason, modeling approach is widely applied to determine fine root biomass and turnover from easily measurable stand parameters, such as leaf area index (LAI), foliage and above-ground biomass and others (Liu et al. 2004, Yuan et al. 2018). Kriiska et al. (2021) found that the decomposition model for green tea can be used to determine the rate of the fine root decomposition.

Copyright (C) 2021 The Authors. Published by Vytautas Magnus University. This is an open-access article distributed under the terms of the Creative Commons Attribution License (CC BY 4.0), which permits unrestricted use, distribution, and reproduction in any medium, provided the original author and source are credited. 
Ground vegetation is another crucial yet often neglected component of forest ecosystems regarding litter and C budgets. The share of C stock in forests in ground vegetation ranges from 4\% to 13\% (Mälkönen, 1974; Havas and Kubin, 1983). Because of the easily decomposable litter and fast turnover ground vegetation contributes significantly to nutrient cycles in forests, despite constituting only a small proportion of biomass (Mälkönen, 1974; Palviainen et al., 2005). Forest stands undergo structural changes during their development, which changes light availability to the understory, therefore stand age is a significant predictor of ground vegetation and can be used as an input attribute in modelling approach (Muukkonen and Mäkipää, 2006).

The aim of the study was to determine the impact of above- and below-ground as well as ground vegetation litter turnover on $\mathrm{C}$ cycling in forests with drained and naturally wet nutrient-rich organic soils in Latvia to improve National GHG inventory and to integrate data into AGM and EPIM models.

\section{STUDY SITES AND METHODS}

The study was conducted in 46 research sites in Latvia. Tree above-ground litter were collected in 67 research sites representing typical forests with drained and naturally wet organic soils in hemiboreal region. The forest site types on drained organic soils are Callunosa turf. mel. (relatively low soil fertility), Vacciniosa turf. mel. (moderate soil fertility), Myrtillosa turf. mel. (relatively high soil fertility), and Oxalidosa turf. mel. (relatively high soil fertility), but forest site types on naturally wet organic soils are Dryopterioso-caricosa and Filipendulosa (relatively high soil fertility) based on Bušs (1981). The research sites were dominated by Scots pine (Pinus sylvestris L.), Norway spruce (Picea abies (L.) H.Karst.), Silver birch (Betula pendula Roth) and Black alder (Alnus glutinosa).

Tree above-ground litter was collected monthly using 5 collectors placed randomly in each site over a period of 1 year. Collector design was the following: the collecting area of individual traps $-0.42 \mathrm{~m}^{2}$, solid funnel (0.7 $\mathrm{m}$ deep) with nylon bag with mesh size of $0.2 \mathrm{~mm}$. At the laboratory, dry matter of litter was determined by drying samples at $105^{\circ} \mathrm{C}$ temperature. Total $\mathrm{C}$ concentration of the ground litter samples (dried at $70{ }^{\circ} \mathrm{C}$ temperature) were determined by total combustion at $950^{\circ} \mathrm{C}$ with elemental analyzer Elementar EL Cube according to the LVS ISO 10694:2006 and ISO 13878:1998, respectively.

A model to estimate fine root biomass was chosen from the compilation of Neumann et al. (2019), where stem biomass is required as input data (given in equation 1).

$$
\text { Fine root biomass }\left(t h a^{-1}\right)=\text { stem biomass }\left(t h a^{-1}\right) \times 0.02
$$

Next, the biomass value was multiplied by fine root turnover rate $\left(\mathrm{yr}^{-1}\right)$ to calculate the annual tree below-ground litter input. We used the turnover rates in boreal forests for Betula $(1.22 \pm 0.56)$, broadleaves $(1.15 \pm 0.23)$, Picea (0.84 $\pm 0.07)$ and Pinus $(0.61 \pm 0.17)$ from the review of Yuan and Chen (2010). The $\mathrm{C}$ content in biomass was assumed 51\% for conifers and 48\% for broadleaves (Lamlom and Savidge 2003, IPCC 2006).

We used the equations from the study of Muukkonen and Mäkipää (2006). Ground vegetation biomass $\left(\mathrm{kg} \mathrm{ha}^{-1}\right)$ was calculated for spruce, pine, alder and birch forest stands and separately for each plat form: mosses, lichens, dwarfshrubs, herbs and grasses (equations 2-11). The input variable is stand age in years.

Pine forest stands:

Above-ground biomass (y), dwarf shrubs:

$$
\sqrt{y+0.5}=16.68+0.129 \mathrm{x} \text { stand age }+0.0004 \mathrm{x} \text { stand age } e^{2}
$$

Above-ground biomass (y), herbs and grasses:

$$
\sqrt{y+0.5}=11.725-0.098 \times \text { stand age }+0.0002 \times \text { stand age }^{2}
$$

Above-ground biomass (y), mosses:

$$
\sqrt{y+0.5}=27.329+0.138 \mathrm{x} \text { stand age }-0.0005 \mathrm{x} \text { stand age } e^{2}
$$

Above-ground biomass (y), lichens:

Spruce forest stands:

$$
\sqrt{y+0.5}=7.975-0.0002 \times \text { stand } a g e^{2}
$$

Above-ground biomass (y), dwarf-shrubs:

$$
\begin{gathered}
\sqrt{y+0.5}=10.375-0.033 \times \text { stand age }+0.001 \times \text { stand age } e^{2} \\
-0.000004 \times \text { stand age }
\end{gathered}
$$

Above-ground biomass, herbs and grasses:

$$
\sqrt{y+0.5}=15.058-0.113 \times \text { stand age }+0.0003 \times \text { stand age } e^{2}
$$


Above-ground biomass (y), mosses:

$$
\sqrt{y+0.5}=19.282+0.164 \mathrm{x} \text { stand age }-0.000001 \mathrm{x} \text { stand age }{ }^{3}
$$

Broad-leaved forest stands:

Above-ground biomass (y), dwarf-shrubs:

$$
\sqrt{y+0.5}=7.102+0.0004 \times \text { stand age } e^{2}
$$

Above-ground biomass (y), herbs and grasses:

$$
\begin{gathered}
\sqrt{y+0.5}=20.58-0.423 \times \text { stand age }+0.004 \times \text { stand ag } \mathrm{e}^{2} \\
-0.00002 \times \text { stand age }
\end{gathered}
$$

Above-ground biomass (y), mosses:

$$
\sqrt{y+0.5}=13.555-0.056 * \text { stand age }
$$

To calculate above-ground vegetation litter, the obtained values were multiplied by the turnover rates of the respective plant forms -0.25 for dwarf-shrubs, 1 for herbs and grasses, 0.33 for mosses and 0.1 for lichens (Muukkonen 2006). It was assumed that the proportion of the ground vegetation biomass located in the below-ground parts is $70 \%$ of the total biomass (Mälkönen 1974, Palviainen et al. 2005). To calculate C input with ground vegetation litter, it was assumed that the $\mathrm{C}$ fraction in biomass is 0.475 (FAO 2005).

\section{RESULTS AND DISCUSSION}

The average annually produced biomass of tree above-ground litter was within the range from $0.61 \pm 0.14 \mathrm{tha}^{-1} \mathrm{yr}^{-1}$ in a Norway spruce stand, which is the youngest forest stand included in the study and characterized with the lowest stem biomass and stand parameters, to $7.26 \pm 0.37 \mathrm{t} \mathrm{ha}^{-1} \mathrm{yr}^{-1}$ in another Norway spruce dominated stand with relatively high stem biomass parameters. Average annually produced biomass of tree above-ground litter in all research sites was $3.76 \pm 0.23 \mathrm{t}$ $\mathrm{ha}^{-1} \mathrm{yr}^{-1}$. The amount of above-ground litter varies, depending on dominant tree species and stand age. For Black alder and Norway spruce there is a trend for the amount of above-ground litter to increase with stand age, whereas for Silver birch the increase is negligible and for Scots pine there is a slight decrease. Neumann et al. (2018) estimated that the average annual above-ground litter production rate for Fennoscandia and Baltic states (mainly for boreal forests) is $3.22 \pm 2.01 \mathrm{tha}^{-1} \mathrm{yr}^{-1}$ for conifers and $2.76 \pm 1.27 \mathrm{t} \mathrm{ha}^{-1} \mathrm{yr}^{-1}$ for broadleaves. The average value of our estimated litter input falls within their estimates, however in the Norway spruce stands the amount exceeds the value for conifer stands about 2.6 times.

Annual $\mathrm{C}$ input through tree above-ground litter is shown in Figure 1. There is a trend for litter biomass and $\mathrm{C}$ input to increase along with increasing stand basal area. In stands with a basal area ranging from 2.5 to $50 \mathrm{~m}^{2} \mathrm{ha}{ }^{-1}$, the highest total $\mathrm{C}$ annual input was estimated in Norway spruce dominated stands with a basal area of $40 \mathrm{~m}^{2} \mathrm{ha}^{-1}$, but the smallest total annual C input was estimated in Scots pine and Black alder dominated stands, respectively, with a basal area of 5.25 and $2.52 \mathrm{~m}^{2} \mathrm{ha}^{-1}$ (Figure 1). Generally, C content in conifer trees is larger than that in broadleaves because of higher lignin content in the former (Lamlom and Savidge, 2003). Exceptions have been observed in northern Europe, which is also stated in our results (Neumann et al., 2018).

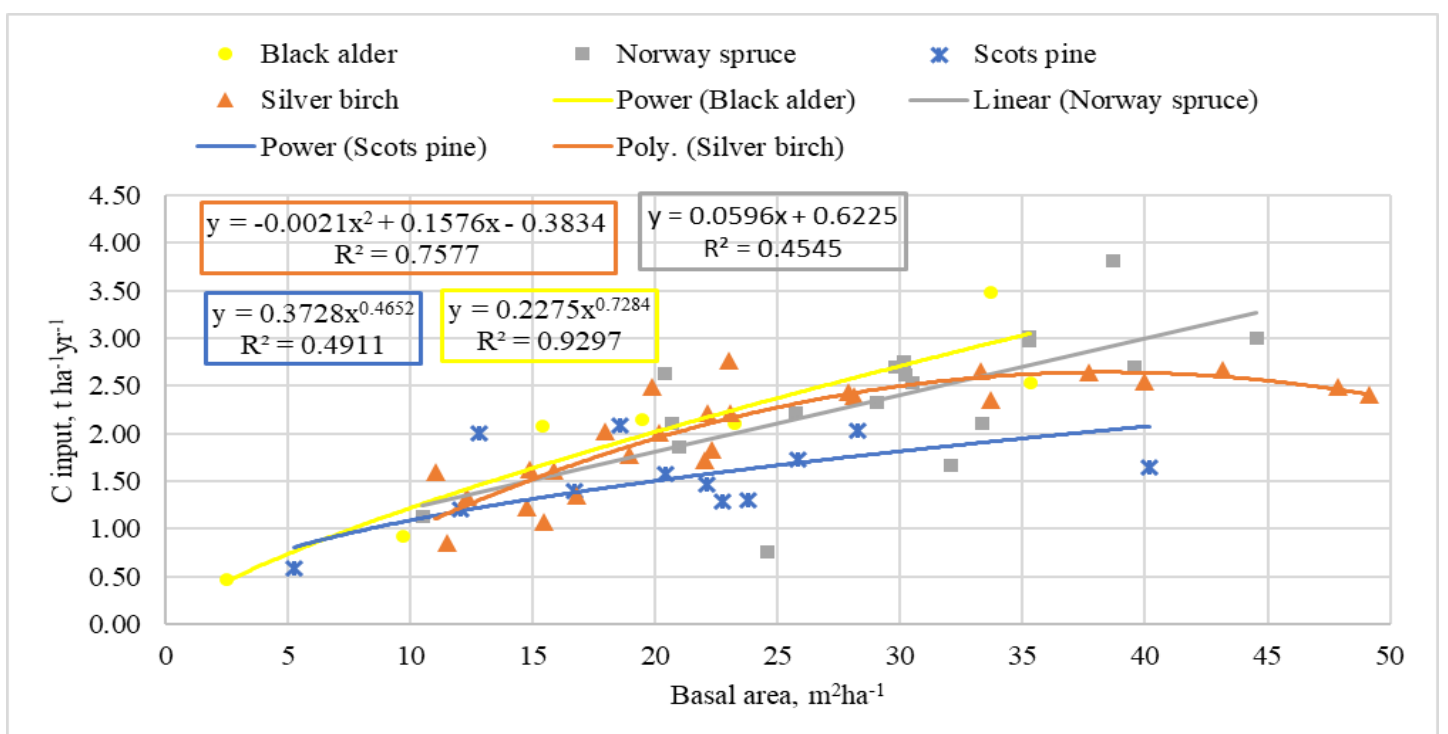

Figure 1. Annual $\mathrm{C}$ input with tree above-ground litter in forest stands with different dominant tree species depending on stand basal area 
Modeled $\mathrm{C}$ annual input through tree below-ground (fine root) litter is shown in Figure 2. In Silver birch dominated stands the average annual $\mathrm{C}$ input was $1.43 \pm 0.16 \mathrm{t} \mathrm{ha}^{-1} \mathrm{yr}^{-1}$, in Black alder dominated stands $-0.88 \pm 0.30 \mathrm{tha}^{-1} \mathrm{yr}^{-1}$, in Norway spruce dominated stands $-1.04 \pm 0.12 \mathrm{t} \mathrm{ha}^{-1} \mathrm{yr}^{-1}$ and in Scots pine dominated stands $-0.54 \pm 0.12 \mathrm{t} \mathrm{ha}^{-1} \mathrm{yr}^{-1}$. The highest annual $\mathrm{C}$ input (3.70 $\mathrm{t} \mathrm{ha}^{-1} \mathrm{yr}^{-1}$ ) was estimated in a Silver birch stand at age of 68 years, but the lowest $\mathrm{C}$ input was estimated in a young stand of Black alder, 10 years age $\left(0.069 \mathrm{ha}^{-1} \mathrm{yr}^{-1}\right)$. According to a Swedish study, the input of $\mathrm{C}$ with fine root litter was the highest in spruce stands $\left(1.3 \mathrm{t} \mathrm{C} \mathrm{ha}^{-1} \mathrm{yr}^{-1}\right)$, whereas in pine stands it was $1.06 \mathrm{t} \mathrm{C}^{-1} \mathrm{yr}^{-1}$ and in birch stands $-0.77 \mathrm{t} \mathrm{C} \mathrm{m}^{-2} \mathrm{yr}^{-1}$ (Hansson et al. 2011). Results show a positive trend for $\mathrm{C}$ input of fine-root litter to increase along with stand basal area. The trend is more pronounced in Silver birch stands. Also the amount of fine-root litter and therefore - $\mathrm{C}$ input is higher in Silver birch stands.

Our average estimates are lower than those in results of other studies carried out in the boreal region. The reason for overestimation and underestimation could be the lack of availability of LAI or foliage biomass data. Estimation models with these parameters as input date would provide more accurate results. Our estimated results will be compared with fine root litter measurements from ingrowth cores.

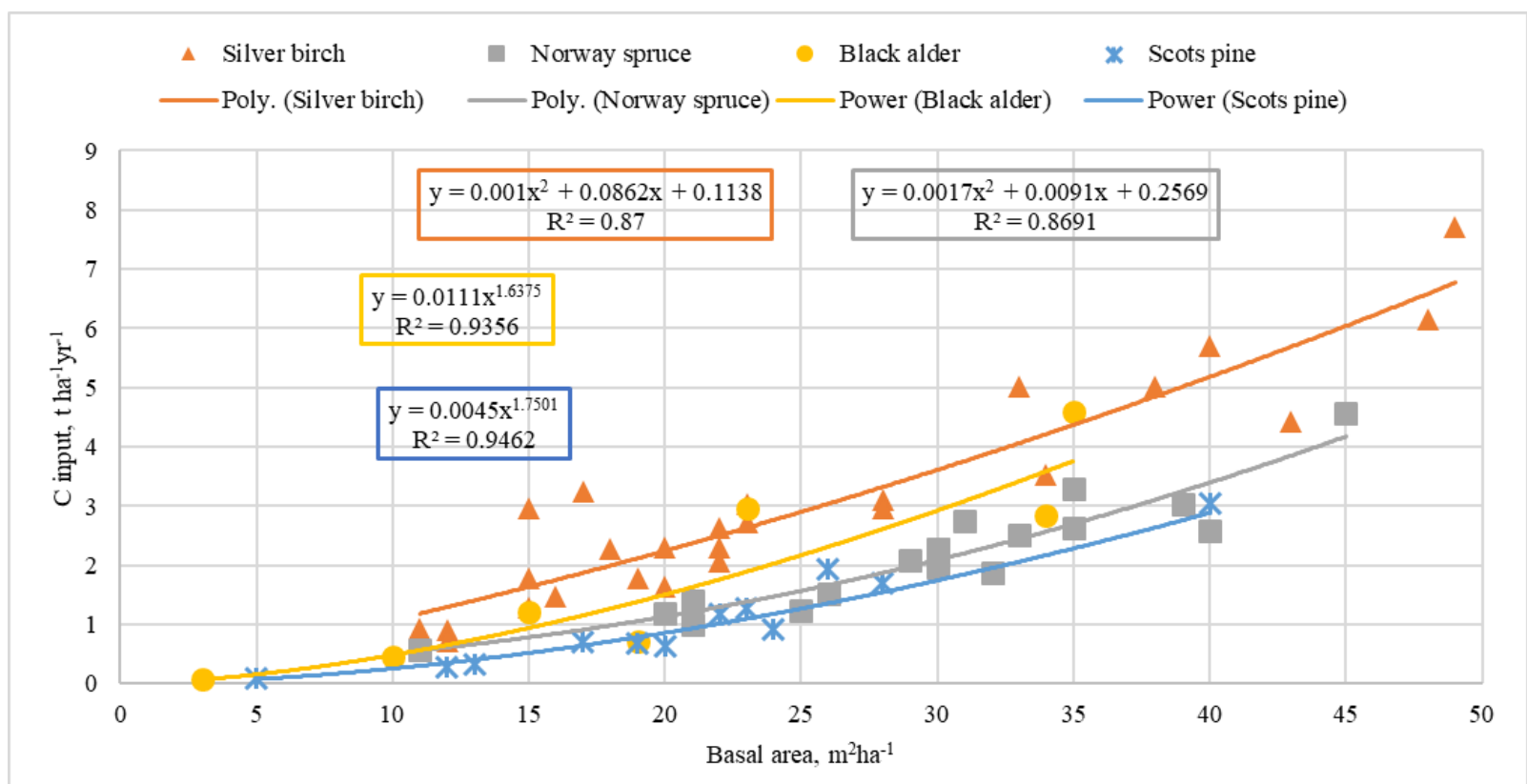

Figure 2. Annual $\mathrm{C}$ input with fine-root litter in forest stands with different dominant tree species depending on stand basal area

The total modeled $\mathrm{C}$ annual input through ground vegetation litter (herbs, grasses, dwarf shrubs, mosses and lichens) is shown in Figure 3. The average annual $\mathrm{C}$ input through above-ground and below-ground litter of ground vegetation was $0.28 \pm 0.01 \mathrm{t} \mathrm{ha}^{-1} \mathrm{yr}^{-1}$ in Silver birch dominated stands, $0.34 \pm 0.05 \mathrm{tha}^{-1} \mathrm{yr}^{-1}$ in Black alder stands, $0.61 \pm$ $0.0010 \mathrm{t} \mathrm{ha}^{-1} \mathrm{yr}^{-1}$ in Norway spruce stands and $1.04 \pm 0.06 \mathrm{t} \mathrm{ha}^{-1} \mathrm{yr}^{-1}$ in Scots pine stands.

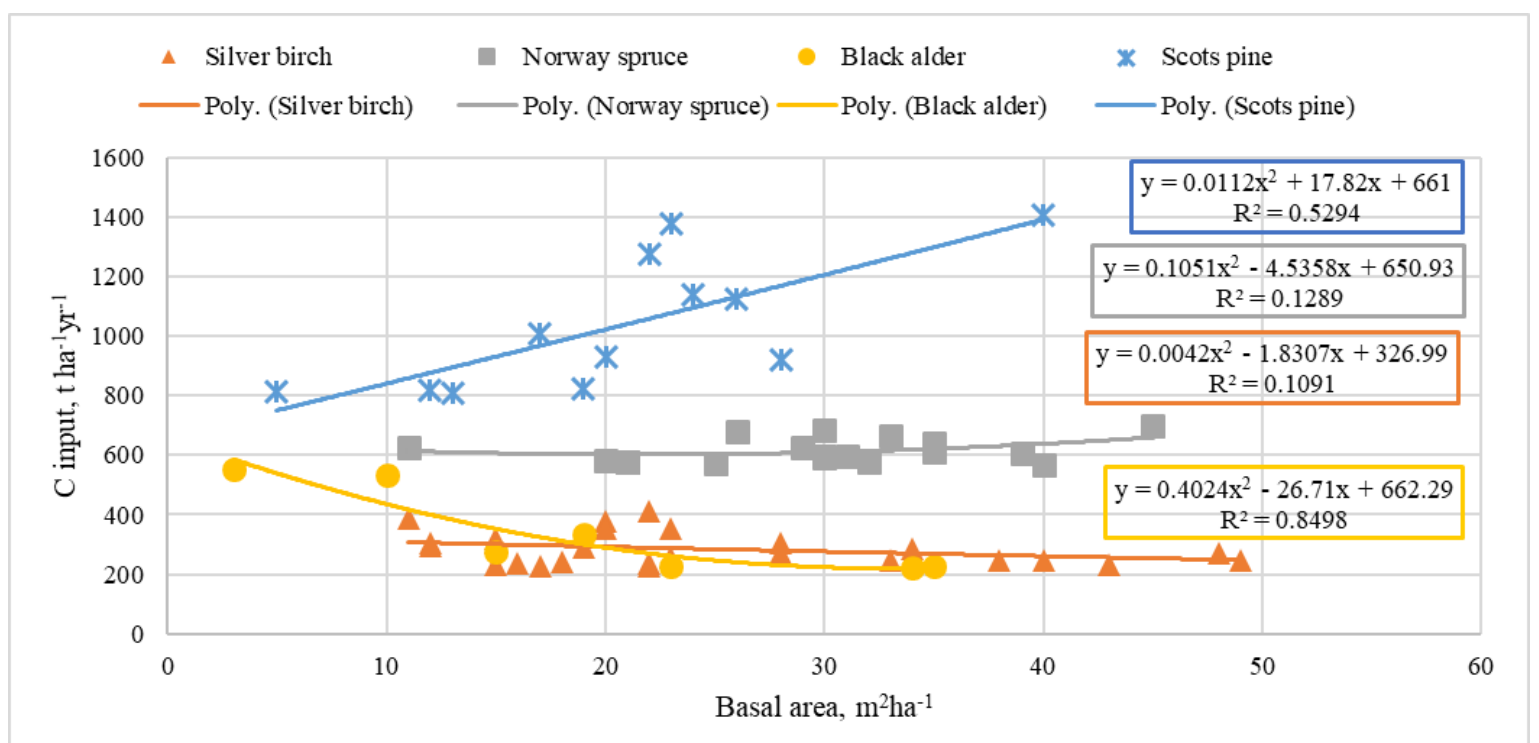

Figure 3. Annual $\mathrm{C}$ input with ground vegetation litter in forest stands with different dominant tree species depending on stand basal area 
In Silver birch and Black alder stands, the largest share of $\mathrm{C}$ input through above-ground litter of ground vegetation constitute herbs and grasses (68 and $70 \%$ of total $\mathrm{C}$ input, respectively). The second largest share of $\mathrm{C}$ input through above-ground litter of ground vegetation forms mosses (22\% of total C input). In Scots pine and Norway spruce stands, the largest share of $\mathrm{C}$ input through above-ground litter of ground vegetation forms mosses (55\% and 63 of total $\mathrm{C}$ input, respectively). In Scots pine stands a significant share constitute dwarf-shrubs (34\%).

Previous studies show that forest stand age strongly influences ground vegetation composition, mainly because of differences in canopy cover (Bäcklund et al. 2015, Majasalmi and Rautiainen, 2020). The lower vegetation litter production in the birch stands and broadleaf stands in general could be explained by lower light availability as a result of a denser canopy. Differences in light availability to ground vegetation could also explain differences between pine and spruce-dominated stands. The study carried out by Muukkonen and Mäkipää (2006) indicates that equations including site attributes, such as latitude, longitude, temperature sum, nutrient level, elevation, number of trees per ha, basal area, stem volume and stand age would offer more accurate estimates than using equations with stand age alone as input alone. However, these detailed equations were developed as country-specific and could be applied only in Finland. In order to improve our estimates, it is necessary to develop country-specific biomass equations for ground vegetation for forests in Latvia.

\section{CONCLUSIONS}

1. There is a trend for above- and below- ground litter biomass and $\mathrm{C}$ input to increase along with increasing stand basal area. The effect on stand age vary between tree species.

2. In conifer stands the $C$ input with ground vegetation increases with stand basal area, whereas for broadleaves there is a slightly decreasing trend. It might be caused by different light levels reaching ground vegetation through canopy.

3. The improvement of the modeling approach to estimate $\mathrm{C}$ stock in tree below-ground and vegetation litter requires additional data (such as input variables) and country-specific models.

Acknowledgement. This study was funded through the project of the Latvian council of science "Evaluation carbon input with aboveand below-ground litter in forests on drained and naturally wet organic soils", LZP-2020/2-0193, 01.12.2020-31.12.2021.

\section{REFERENCES}

1. Bäcklund S., Jönsson M., Strengbom J., Thor G. 2015. Composition of functional groups of ground vegetation differ between planted stands of non-native Pinus contorta and native Pinus sylvestris and Picea abies in northern Sweden. Silva Fennica, Vol. 49, ID 1321. https://doi.org/10.14214/sf.1321

2. Bušs, K. 1981. Meža ekoloǵija un tipologija (Forest ecology and typology). Zinātne, Rīga

3. Drösler M., 2005. Trace Gas Exchange of Bog Ecosystems, Southern Germany. PhD thesis. Technical University Munich, Freising, Germany.

4. FAO. 2005. Knowledge reference for national forest assessments - modeling for estimation and monitoring. Available at: http://www.fao.org/forestry/17111/en/(accessed on 11 September 2021).

5. Feng C., Wang Z., Yan M., Songling F. Chen H.Y.H. 2019. Increased litterfall contributes to carbon and nitrogen accumulation following cessation of anthropogenic disturbances in degraded forests. Forest Ecology and Management, Vol. 432, pp. 832-839. https://doi.org/10.1016/j.foreco.2018.10.025

6. Hansson K., Olsson B.A., Olsson M., Johansson U. Kleja D.B. 2011. Differences in soil properties in adjacent stands of Scots pine, Norway spruce and silver birch in SW Sweden. Forest Ecology and Management, Vol. 262, pp. 522-30. https://doi.org/10.1016/j.foreco.2011.04.021

7. Havas P., Kubin E. 1983. Structure, growth and organic matter content in the vegetation cover of an old spruce forest in northern Finland. Annales Botanici Fennici, Vol. 20, pp.115-149.

8. IPCC. 2006. 2006 IPCC Guidelines for National Greenhouse Gas Inventories, Prepared by the National Greenhouse Gas Inventories Programme. In: H.S. Eggleston, L. Buendia, K. Miwa, T. Ngara and K. Tanabe (Editors), IGES, Japan. Available online at: https://www.ipcc-nggip.iges.or.jp/public/2006gl/vol4.html

9. Jauhiainen J., Alm J., Bjarnadottir B., Callesen I., Christiansen J. R., Clarke N., Dalsgaard L., He H., Jordan S., Kazanavičiūtė V., Klemedtsson L., Lauren A., Lazdins A., Lehtonen A., Lohila A., Lupikis A., Mander Ü., Minkkinen K., Kasimir Å., Laiho R. 2019. Reviews and syntheses: Greenhouse gas exchange data from drained organic forest soils - a review of current approaches and recommendations for future research. Biogeosciences, Vol. 16, pp. 4687-4703. https://doi.org/10.5194/bg-16-4687-2019

10. Kriiska K., Lõhmus K., Frey J., Asi E., Kabral N., Napa Ü., Ostonen. I. 2021. The Dynamics of Mass Loss and Nutrient Release of Decomposing Fine Roots, Needle Litter and Standard Substrates in Hemiboreal Coniferous Forests. Frontiers in Forests and Global Change, Vol. 4, pp. 1-14. https://doi.org/10.3389/ffgc.2021.686468

11. Lamlom S.H., Savidge R.A. 2003. A reassessment of carbon content in wood: variation within and between 41 North American species. Biomass and Bioenergy, Vol. 25, pp. 381-388. https://doi.org/10.1016/S0961-9534(03)00033-3

12. Latvia's National Inventory Report. 2021. Available at: https://unfccc.int/ghg-inventories-annex-i-parties/2021 (accessed on 11 September 2021).

13. Lazdiņš A., Lupiķis A. 2019. LIFE REstore project contribution to the greenhouse gas emission accounts in Latvia. In: Priede A., Gancone A. (eds.) 2019. Sustainable and responsible after-use of peat extraction areas. Baltijas krasti, Riga, pp. 21-54 
14. Lehtonen A. 2005. Carbon stocks and flows in forest ecosystem based on forest inventory data. Dissertationes Forestales, Vol. 11, https://doi.org/10.14214/df.11

15. Liu C., Westman C.J., Berg B., Kutsch W., Wang G.Z., Man R. Ilvesniemi H. 2004. Variation in litterfall-climate relationships between coniferous and broadleaf forests in Eurasia. Global Ecology and Biogeography, Vol. 13, pp. $105-114$. https://doi.org/10.1111/j.1466-882X.2004.00072.x

16. Majasalmi T. Rautiainen M. 2020. The impact of tree canopy structure on understory variation in a boreal forest. Forest Ecology and Management, Vol. 466, ID 118100. https://doi.org/10.1016/j.foreco.2020.118100

17. Mälkönen E. 1974. Annual primary production and nutrient cycle in some Scots pine stands. Communicationes Instituti Forestalis Fenniae, Vol. 84, pp. 1-87.

18. Mccormack M., Dickie I., Eissenstat D., Fahey T., Fernandez C., Guo D., Helmisaari H-S., Hobbie E., Iversen C., Jackson R., Leppälammi-Kujansuu J., Norby R., Phillips R., Pregitzer K., Pritchard S., Rewald B. Zadworny M. 2015. Redefining fine roots improves understanding of belowground contributions to terrestrial biosphere processes. New Phytologist, Vol. 207, pp. 505-518. https://doi.org/10.1111/nph.13363

19. Muukkonen P. 2006. Forest inventory-based large-scale forest biomass and carbon budget assessment: new enhanced methods and use of remote sensing for verification. Dissertationes Forestales, Vol. 30, 48 pp. https://doi.org/10.14214/df.30

20. Muukkonen P., Mäkipää R. 2006. Empirical biomass models of understorey vegetation in boreal forests according to stand and site attributes. Boreal Environment Research, Vol. 11, pp. 355-69.

21. Neumann M., Ukonmaanaho L., Johnson J., Benham S., Vesterdal L., Novotný R., Verstraeten A., Lundin L., Thimonier A., Michopoulos P., Hasenauer H. 2018. Quantifying carbon and nutrient input from litterfall in European forests using field observations and modeling. Global Biogeochemical Cycles, Vol. 32, pp. 784-798. https://doi.org/10.1029/2017GB005825

22. Neumann M., Godbold D., Hirano Y., Finér, L. 2019. Improving models of fine root carbon stocks and fluxes in European forests. Journal of Ecology, Vol. 108(2), pp. 496-514. https://doi.org/10.1111/1365-2745.13328

23. Palviainen M., Finér L., Mannerkoski H., Piirainen S., Starr M. 2005. Responses of ground vegetation species to clear-cutting in a boreal forest: Aboveground biomass and nutrient contents during the first 7 years. Ecological Research, Vol. 20, pp. 652-660. https://doi.org/10.1007/s11284-005-0078-1

24. Tubiello F.N., Biancalani R., Salvatore M., Rossi S., Conchedda G., 2016. A worldwide assessment of greenhouse gas emissions from drained organic soils. Sustainability, Vol. 8, pp. 1-13. https://doi.org/10.3390/su8040371

25. Turunen J., Tomppo E., Tolonen K., Reinikainen A. 2002. Estimating carbon accumulation rates of undrained mires in Finlandapplication to boreal and subarctic regions. The Holocene, Vol. 12, pp $69-80$. https://doi.org/10.1191/0959683602hl522rp

26. Wutzler T., Mund M. 2007. Modelling mean above and below ground litter production based on yield tables. Silva Fennica, Vol. 41, pp. 559-574. https://doi.org/10.14214/sf.289

27. Yu Z., Loisel J., Brosseau D.P., Beilman D.W., Hunt S.J. 2010. Global peatland dynamics since the Last Glacial Maximum. Geophysical Research Letter, Vol. 37, L13402. https://doi.org/10.1029/2010GL043584

28. Yuan Z.Y., Chen H.Y.H. 2012. Indirect Methods Produce Higher Estimates of Fine Root Production and Turnover Rates than Direct Methods. PloS one, Vol. 7(11), e48989. https://doi.org/10.1371/journal.pone.0048989.

29. Yuan Z.Y., Shi X.R., Jiao F. Han F.P. 2018. Changes in fine root biomass of Picea abies forests: Predicting the potential impacts of climate change. Journal of Plant Ecology, Vol. 11, pp 595-603. https://doi.org/10.1093/ipe/rtx032 